\title{
PENENTUAN WAKTU PENDIRIAN DAN KAPASITAS PRODUKSI PABRIK ZIRKON OKSID KLORID (ZOC) DI INDONESIA
}

\author{
Sugili Putra ${ }^{1}$, Tunjung Indrati Yulianti ${ }^{2}$ \\ ${ }^{1}$ Sekolah Tinggi Teknologi Nuklir - BATAN \\ ${ }^{2}$ Pusat Teknologi Akselerator dan Proses Bahan - BATAN \\ Email: sugili@batan.go.id
}

\begin{abstract}
ABSTRAK
PENENTUAN WAKTU PENDIRIAN DAN KAPASITAS PRODUKSI PABRIK ZIRKON OKSID KLORID (ZOC) DI INDONESIA. Telah dilakukan penelitian Penentuan Waktu Pendirian dan Kapasitas Produksi Pabrik Zirkon Oksid Klorid di Indonesia. Proses yang digunakan sebagai dasar perhitungan adalah teknologi pengolahan Zirkonium yang telah dikuasai oleh Pusat Teknologi Akselerator dan Proses Bahan - Badan Tenaga Nuklir Nasional. Penentuan waktu pendirian dan kapasitas pabrik dilakukan dengan cara analisis Break Even Point (BEP). Input perhitungan dalam analisis BEP didapatkan dengan cara peramalan. Hasil penelitian menunjukkan bahwa pabrik ZOC dapat didirikan mulai tahun 2012 dengan kapasitas produksi ZOC sebesar 2040,2655 ton/tahun, kapasitas terpasang 30377,0358 ton/tahun, dan waktu yang dibutuhkan untuk pengembalian modal adalah 55 bulan operasi.
\end{abstract}

Kata kunci: BEP, kapasitas produksi, pengolahan Zirkonium, peramalan, ZOC.

\section{ABSTRACT}

DETERMINATION OF ESTABLISHMENT TIME AND THE PRODUCTION CAPACITY OF ZIRCON OXIDE CHLORIDE (ZOC) PLANT IN INDONESIA. Determination of establishment time and the production capacity of Zircon Oxide Chloride in Indonesia have been done. The process used as the basis for calculating is the processing tecnology that has been dominated by Center of Accelerator Technology and Material Process - National Nuclear Energy Agency. Timing of the establishment and capacity of the plant is done by analysis of Break Even Point (BEP). Input in the calculation BEP analysis obtained by forecasting. The results showed that the plant can be established in 2012 with ZOC prodtiction capacity is 2040.2655 tons/year, installed capacity is 30377.0358 tonsyear, and the amount of time required for parback is 55 months of operation.

Keywords: BEP, forecasting, processing Zirconium, production capacity, ZOC.

\section{PENDAHULUAN}

Salah satu bentuk sumber daya mineral adalah bahan galian logam (bijihiore). Bahan galian logam merupakan bahan galian yang apabila diolah dengan teknologi tertentu akan dapat dimanfaatkan logamnya. Suatu produk manufaktur yang dibuat dari logam yang diolah dari bahan galian sering memerlukan bahan baku logam dengan kadar yang bervariasi scsuai dengan persyaratan yang telah ditetapkan.

Zirkonium adalah salah satu bahan mineral dengan karakter seperti tersebut di atas.
Produk mineral zirkonium dapat digolongkan menjadi tiga golongan besar yaitu, grade nuklir, grade $>90 \%$, dan grade $>65 \%$. Zirkonium grade nuklir adalah produk zirkonium yang digunakan dalam teknologi nuklir dengan kadar Zr tertinggi, yaitu hampir 100\%. Tidak hanya kemurnian yang tinggi, produk grade nuklir ini juga mensyaratkan sisa pengotor yang masih ada adalah bukan bahan yang mempunyai tampang lintang serap neutron yang tinggi. Zirkonium grade $>90 \%$ adalah produk zirkonium dengan kadar lebih besar dari 90\%. Zirkonium grade ini digunakan 
untuk aplikasi khusus dengan persyaratan tertentu yang sesuai dengan sifat fisika dan kimia zirkonium. Sedangkan zirkonium grade $>65 \%$ adalah produk zirkonium dengan kadar $>65 \%$ dan digunakan terutama untuk pembuatan keramik.

Pusat Teknologi Akselerator dan Proses Bahan, Badan Tenaga Nuklir Nasional (PTAPB-BATAN) Yogyakarta telah menguasai proses pengolahan zirkonium. Di PTAPBBATAN hasil litbang mengenai pengolahan pasir zirkon menjadi $\mathrm{ZrO}_{2}$ sudah melewati tahapan penelitian dasar dan telah ditingkatkan menjadi kegiatan penelitian yang berupa penguatan kompetensi teknik. Tahapan tersebut dilakukan dengan perancangan berbasis model matematik sehingga menghasilkan suatu prototipe alat proses. Berdasarkan tahapan proses tersebut akan dapat dihasilkan dua grade kemurnian zirkonium. Kedua grade tersebut adalah, grade zirkonium dengan kemurnian $>65 \%$ dan $>90 \%$.

Teknologi pengolahan zirkonium yang telah dikuasai ini menjadi tidak akan ada artinya jika tidak digunakan. Seandainya akan dibangun pabriknya maka akan muncul masalah kapan harus dilakukan pembangunan pabrik dan berapa kapasitasnya. Untuk dapat membantu memecahkan permasalahan tersebut maka dilakukan penelitian ini. Penelitian dilakukan dengan cara menghitung kebutuhan ZOC (Zircon Oxide Chloride) pada suatu waktu tertentu, sehingga selain akan diketahui waktu yang tepat untuk membangun pabrik juga akan ditentukan berapa kapasitas pabrik yang tepat untuk dapat memenuhi kebutuhan ZOC selama periode tertentu. Perhitungan kebutuhan dilakukan dengan cara peramalan yang meliputi, jumlah permintaan (baik permintaan dari dalam negeri maupun dari luar negeri), harga jual produk, harga alat proses, harga bahan baku dan bahan kimia, serta data perbankan (meliputi bunga bank, kurs rupiah terhadap dolar, dan inflasi).

\section{TEORI}

\section{Metode Peramalan}

Terdapat beberapa metode yang dapat digunakan untuk mengidentifikasi pola suatu data, antara lain: visual, autokorelasi, regresi, dan dekomposisi klasik. Metode visual merupakan metode yang paling umum digunakan. Dewasa ini, metode tersebut lazim diposisikan sebagai media awal yang memberikan gambaran kasar mengenai pola yang mungkin diwakili oleh suatu data, seperti trend, musiman, siklus, dan random. Karena informasi yang diperoleh dari metode visual bersifat kasar, proses identifikasi selayaknya didukung oleh metode yang bersifat kuantitatif. Ketepatan peramalan diukur dengan menggunakan beberapa ukuran $^{[1]}$ sebagai berikut :

\section{Error (et)}

$$
e_{t}=Y_{t}-\hat{Y}_{t}
$$

dengan $Y$ : nilai data

$$
\text { : nilai hasil peramalan }
$$

\section{Sum Square Error (SSE)}

$$
\begin{aligned}
& \text { SSE }=\sum\left(\mathrm{Y}_{\mathrm{j}}-\overline{\mathrm{Y}}_{\mathrm{j}}\right)^{2} \\
& \text { SST }=\left(\sum \mathrm{Y}_{\mathrm{j}}^{2}\right)-\frac{\left(\sum \overline{\mathrm{Y}_{j}}\right)^{2}}{n}
\end{aligned}
$$

dengan :

$n$ : jumlah data

\section{R-Square}

$$
R^{2}=1-\frac{S S E}{S S T}
$$

\section{Standard Deviation of Error (SDE)}

$$
S D E=\sqrt{\frac{\sum e_{t}^{2}}{(n-1)}}
$$

Mean Error (ME)

$$
\mathrm{ME}=\frac{\mathrm{y}_{\mathrm{i}=1}^{\mathrm{n}} e_{\mathrm{t}}}{\mathrm{n}}
$$

\section{Mean Squared Error (MSE)}

$$
\operatorname{MSE}=\frac{\sum e_{t}^{2}}{\mathrm{n}}
$$

Metode statistik yang dapat dipergunakan untuk uji kerandoman diantaranya adalah statistik Durbin-Watson dan statistik-U dari Theil.

\section{Statistik Durbin-Watson}

$$
D W=\frac{\sum_{t=2}^{n}\left(e_{t}-e_{t-1}\right)^{2}}{\sum_{t-1}^{n} e_{t}^{2}}
$$


Statistik-U dari Theil

$$
\mathrm{U}=\sqrt{\frac{\sum_{\mathrm{i}=1}^{\mathrm{n}-1}\left(\frac{\mathrm{Y}_{\mathrm{i}-1}-Y_{i+1}}{Y_{i}}\right)^{2}}{\sum_{\mathrm{i}=1}^{\mathrm{n}-1}\left(\frac{Y_{i+1}-Y_{i}}{Y_{i}}\right)^{2}}}
$$

\section{Capital Investment dan Production Cost}

Penentuan biaya investasi pada penelitian ini dilakukan dengan menggunakan Metode Lang $^{[2]}$. Metode ini didasarkan pada suatu faktor perbandingan pada biaya pemesanan peralatan (delivered equipment cost). Untuk proses padat cair perbandingannya adalah sebagai Tabel 1. Berdasarkan tabel tersebut, maka semua komponen biaya investasi dan biaya produksi akan dapat ditentukan.

\section{Analisis Break Even}

Break Even Point (BEP), yaitu jumlah minimum produk yang harus diproduksi sehingga pabrik akan mengalami titik impas (tidak untung dan tidak rugi). Tiga komponen analisis break even adalah volume, biaya, dan laba. Volume adalah tingkat produksi perusahaan. Terdapat dua jenis biaya dalam proses produksi, yaitu biaya tetap dan biaya variabel. Sedangkan laba adalah selisih antara total pendapatan dan total biaya.

Tabel 1. Faktor Perbandingan untuk Memperkirakan Modal Investasi dengan Didasarkan pada Biaya Pemesanan Peralatan ${ }^{[2]}$.

\begin{tabular}{|c|c|c|c|}
\hline No & Componeni & $\begin{array}{l}\text { Ratio } \\
\text { Factor }\end{array}$ & $\begin{array}{l}\text { Capital } \\
\text { (Rp.) }\end{array}$ \\
\hline 1 & $\begin{array}{l}\text { Purchased equipment } \\
\text { (delivered) }\end{array}$ & 1,00 & \\
\hline 2 & $\begin{array}{l}\text { Purchased equipment } \\
\text { installation }\end{array}$ & 0,39 & \\
\hline 3 & Instrumentation (installed) & 0,13 & \\
\hline 4 & Piping (intalled) & 0.31 & \\
\hline 5 & Electrical (installed) & 0,10 & \\
\hline 6 & Building (including service) & 0,29 & \\
\hline 7 & Yard improvements & 0,10 & \\
\hline 8 & Service facilities (installed) & 0,55 & \\
\hline \multirow[t]{2}{*}{9} & Land & 0,06 & \\
\hline & Total Direct Plant Cost & & $\mathrm{A}=1 \mathrm{~s} / \mathrm{d} 9$ \\
\hline 10 & Engineering and supervision & 0,32 & \\
\hline \multirow[t]{2}{*}{11} & Construction expense & 0,34 & \\
\hline & Total Direct and Indirect Cost & & $B=A+10+11$ \\
\hline 12 & Contractor's Fee & 0,18 & \\
\hline \multirow[t]{2}{*}{13} & Contingency & 0,36 & \\
\hline & Fixed Capital Investment & & $\mathrm{C}=\mathrm{B}+12+13$ \\
\hline \multirow[t]{2}{*}{14} & Working capital & 0,74 & \\
\hline & Total Capital Invesiment & & $\mathrm{D}=\mathrm{C}+14$ \\
\hline
\end{tabular}

Perhitungan untuk menentukan berapa kapasitas pabrik minimal sehingga pabrik jika beroperasi tidak akan mengalami kerugian, digunakan Persamaan $(10)^{[3]}$.

$$
\mathrm{BEP}=\frac{F_{2}+0,3 R_{2}}{S_{2}-V_{2}-0,7 R_{2}} \times 100 \%
$$

dengan :

BEP: Break Even Point

$\mathrm{F}_{\mathrm{a}}$ : annual fixed expense

$\mathrm{R}_{\mathrm{a}}$ : annual regulated expense
$\mathrm{S}_{\mathrm{a}} \quad: \quad$ sales prices

$V_{\mathrm{a}}$ : annual variable expense

Analisis BEP digunakan untuk menentukan kapan suatu pabrik dapat didirikan. Caranya adalah, dengan membuat analisis BEP untuk tiap-tiap tahun tertentu. Jika pada suatu tahun tertentu kapasistas BEP adalah lebih kecil dari pada kebutuhan saat itu, dan kebutuhan tersebut adalah masih di bawah 
kapasitas maksimum pabrik, maka dapat disimpulkan bahwa tahun tersebut layak untuk didirikan pabriknya.

\section{METODE}

Bahan penelitian ini berupa data yang diperlukan dalam pengembangan model untuk menentukan waktu pendirian dan kapasitas produksi pabrik ZOC yaitu sebagai berikut.

1. Data permintaan masing-masing grade produk

2. Data perkembangan harga produk

3. Data harga dan spesifikasi bahan-bahan kimia

4. Data harga dan spesifikasi alat-alat pabrik kimia

5. Data jabatan dan gaji karyawan perusahaan
6. Data potensi dan kadar mineral dalam bijih

7. Data perbankan, meliputi : kurs Rp/\$, bunga bank, dan inflasi

Alat yang diperlukan adalah sebagai berikut:

1. Laptop

2. Program Microsoft Excel 2007

3. Program Minitab 14.

Peramalan dilakukan untuk memperkirakan jumlah permintaan, harga produk, biaya bahan kimia, biaya peralatan, biaya karyawan, dan biaya-biaya lainnya di masa mendatang. Setelah itu dilakukan perhitungan untuk menentukan tahun layak bangun dan kapasitas produksi pabrik. Cara kerja proses penelitian dilakukan mengikuti diagram alir seperti pada Gambar 1.

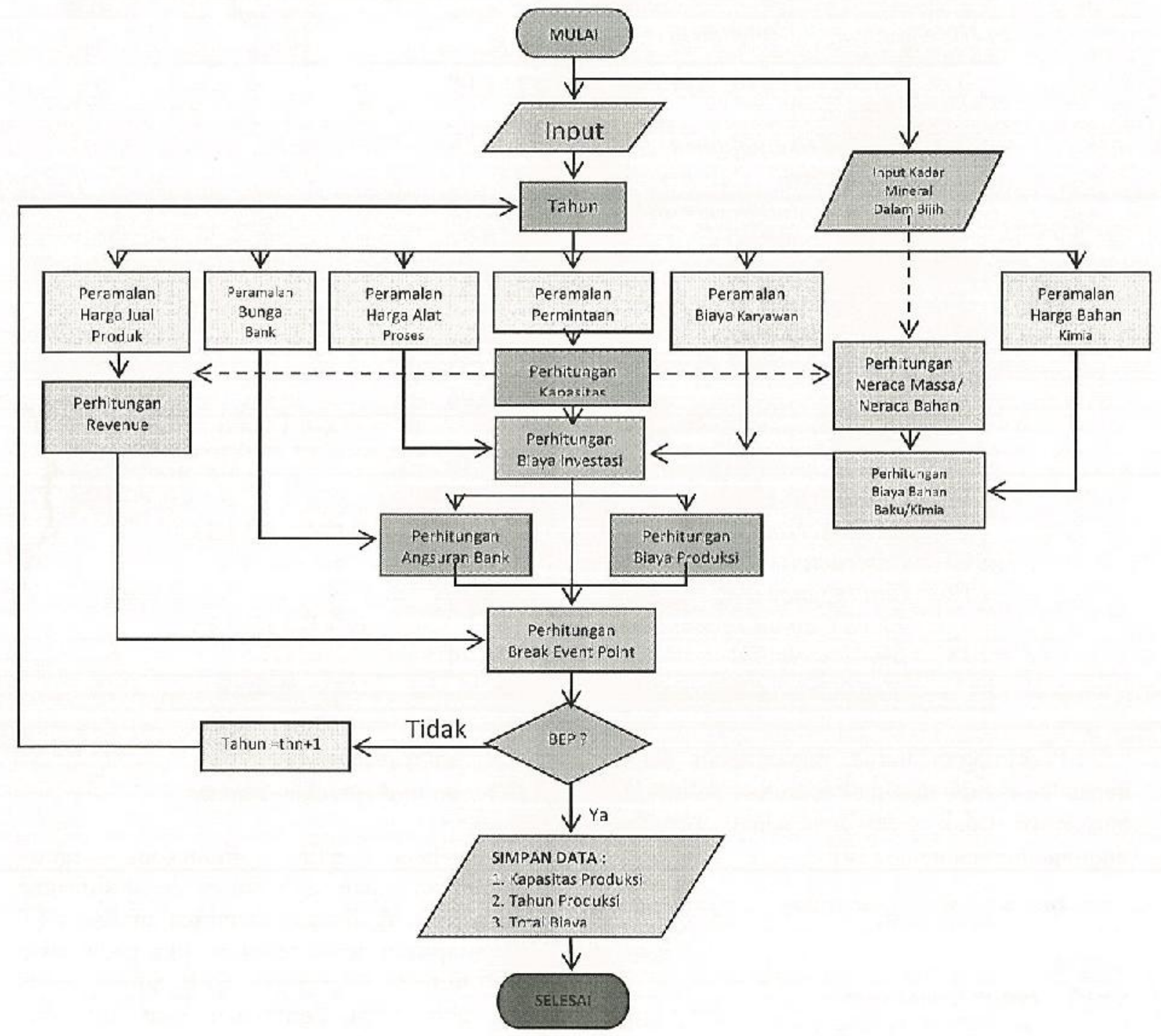

Gambar 1. Diagram Alir Langkah Kerja Penelitian 


\section{HASIL DAN PEMBAHASAN}

\section{Peramalan}

Pada penelitian ini, penentuan persamaan trend dilakukan terhadap tiga macam model persamaan trend. Tiga persamaan trend tersebut adalah, linear $(\mathrm{Y}=\mathrm{aX}+\mathrm{b})$, logaritmic $(\mathrm{Y}=\mathrm{a} \ln (\mathrm{X})+\mathrm{b})$, dan power $\left(\mathrm{Y}=\mathrm{a} \mathrm{X}^{\mathrm{b}}\right)$. Pemilihan tiga model persamaan ini berdasarkan cek awal terhadap semua data yang ada, ternyata hanya tiga model ini saja yang paling mungkin untuk digunakan persamaan trend-nya. Validasi model dilakukan dengan cara membandingkan ukuran ketepatan peramalan, yang meliputi : $\mathrm{R}^{2}$, Standard Deviation Error (SDE), Mean Error (ME), dan Mean Squared Error (MSE). Keempat kriteria ini dianggap sudah mewakili semua ukuran ketepatan peramalan untuk kebutuhan peramalan dalam penelitian ini.

Berikut ini adalah contoh metode peramalan yang dilakukan dalam penelitian ini, yaitu penentuan persamaan untuk meramalkan harga bijih zirkon dunia. Data harga bijih/konsentrat dunia ${ }^{[4]}$ dalam penelitian ini digunakan untuk menghitung harga bahan baku (baik untuk tingkat dunia maupun Indonesia) pada suatu tahun peramalan. Pola data awal adalah seperti terlihat pada Gambar 2 . Berdasarkan gambar tersebut terlihat bahwa antara periode tahun pertama hingga tahun ke56 tidak menunjukkan perkembangan yang berarti, oleh karena itu untuk penentuan pola trend dilakukan pengurangan data.

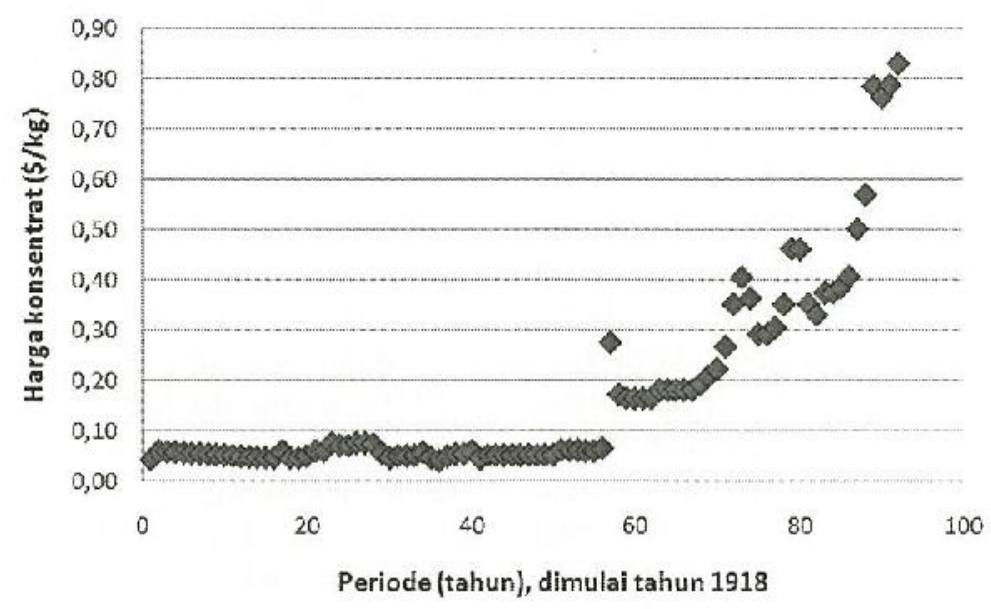

\section{Gambar 2. Pola Data Awal Harga Bahan Baku Zirkonium ${ }^{[4]}$}

Berdasarkan hasil evaluasi terhadap. empat kriteria penilaian ketepatan peramalan, maka didapatkan persamaan harga bijih/konsentrat dunia adalah seperti Persamaan (11). Bentuk pola trend dan validasi terhadap tiga persamaan yang dievaluasai adalah seperti pada Gambar 3.

$$
Y_{1}=0,0061\left(X_{1}-1960\right)^{1,1403}
$$

diperoleh $\mathrm{R}^{2}=0,8198$

dengan :

$Y_{1}$ : harga bijih/konsentrat dunia ( $\left.\$ / \mathrm{kg}\right)$

$X_{1}$ : tahun peramalan 


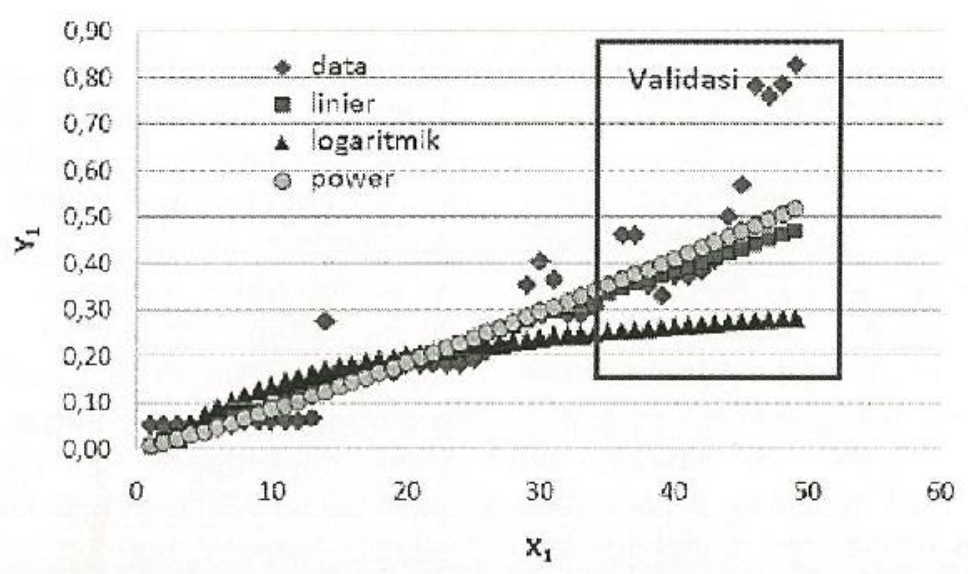

Gambar 3. Pola Trend dan Validasi Harga Bahan Baku Zirkonium

Untuk mengetahui secara keseluruhan hasil perhitungan dalam rangka untuk menentukan model peramalan, maka disajikan Tabel 2.

\section{Neraca Massa}

Hasil perhitungan neraca massa dan neraca bahan menunjukkan bahwa permintaan produk Zirkonium grade $>90 \%$ untuk pasar luar negeri adalah cukup besar, yaitu sebesar $40,06 \%$ dari seluruh aplikasi Zirkonium dunia. Namun hal ini tidak sama dengan permintaan dalam negeri. Berdasarkan perhitungan menunjukkan bahwa untuk pasar dalam negeri hanya sebesar $4 \%$ saja dari seluruh Zirkonium yang dibutuhkan. Padahal jika dicermati sesungguhnya banyak pabrik-pabrik di Indonesia yang sangat memerlukan Zirkonium grade $>90 \%$. Schingga sesungguhnya pasar Zirkonium untuk grade ini masih sangat besar.

Hasil perhitungan jumlah Zirkonium grade $>90 \%$ yang diperlukan, dari tahun ke tahun menunjukkan adanya peningkatan terusmenerus. Hal ini disebabkan adanya peningkatan jumlah permintaan Zirkonium $>90 \%$, terutama untuk konsumsi export. Hasil perhitungan biaya yang diperlukan untuk bahan baku dan bahan kimia juga mengalami peningkatan. Hal ini disebabkan oleh adanya peningkatan jumlah permintaan Zirkonium $>90 \%$, selain itu harga dari bahan kimia dan bahan baku Zirkon juga diramalkan selalu naik. Hasil perhitungan jumlah Zirkonium grade $>90 \%$ dan biaya bahan baku serta bahan kimianya adalah seperti terlihat pada Gambar 4 .

Tabel 2. Hasil Perhitungan untuk Menentukan Model Peramalan ${ }^{22,4,5,6,7,8,9,10,11]}$ Persamaan trend Y, nomor (1) linear; (2) logaritmik, (3) power.

\begin{tabular}{|c|c|c|c|c|c|c|}
\hline No & Pola Trend & $\mathrm{R}^{2}$ & SDE & $\mathrm{ME}$ & MSE & Kesimpulan \\
\hline \multicolumn{7}{|c|}{ Harga konsentrat dunia ${ }^{[4]}$} \\
\hline 1 & $Y=0,0096(X)-0,0014$ & 0,7963 & 0,1835 & 0,1047 & 0,0316 & \\
\hline 2 & $Y=0,0928 \ln (X)-0,0769$ & 0,5830 & 0,2996 & 0,2347 & 0,0841 & \\
\hline 3 & $Y=0,0061(X)^{1,1403}$ & 0,8198 & 0.1603 & 0,0743 & 0,0241 & Digunakan \\
\hline \multicolumn{7}{|c|}{ Harga Zirkonium keramik $^{[5]}$} \\
\hline 1 & $Y=0,1248(X)+1.6394$ & 0,7991 & 0.5220 & $-0,4516$ & 0,2180 & \multirow{3}{*}{ Digunakan } \\
\hline 2 & $Y=0,5783 \ln (X)+1,4923$ & 0,7442 & 0,0438 & 0,0043 & 0,0015 & \\
\hline 3 & $Y=1,5379(X)^{0,2698}$ & 0,7893 & 0,1533 & -0.1305 & 0,0188 & \\
\hline \multicolumn{7}{|c|}{ Harga Zirkonium logam ${ }^{[6]}$} \\
\hline 1 & $Y=4,5028(X)+187,1825$ & 0,7573 & 35,404 & $-31,470$ & 1096,8 & \multirow{3}{*}{ Digunakan } \\
\hline 2 & $Y=27,4814 \ln (X)+172,7746$ & 0,7751 & $8,760 ?$ & -7.5866 & 67.156 & \\
\hline 3 & $Y=174,7568(X)^{0,1303}$ & 0,7908 & 12,307 & $-10,867$ & 132,53 & \\
\hline
\end{tabular}


Tabel 2 Lanjutan

\begin{tabular}{|c|c|c|c|c|c|c|}
\hline \multicolumn{7}{|c|}{ Plant cost index $x^{[2,7,8]}$} \\
\hline 1 & $Y=10,2821(X)+194,5052$ & 0.8882 & 62,144 & $-55,020$ & 3432,8 & \multirow{3}{*}{ Digunakan } \\
\hline 2 & $Y=73,4765 \ln (X)+145,1918$ & 0,9339 & 9,3465 & 7,9812 & 77,650 & \\
\hline 3 & $\mathrm{Y}=162,3998(\mathrm{X})^{0,2812}$ & 0.9536 & 12,713 & $-10,174$ & 143,67 & \\
\hline \multicolumn{7}{|c|}{ Chemical price index ${ }^{[9]}$} \\
\hline 1 & $Y=4,2231(X)+29,0313$ & 0,9687 & 29,232 & 8,8659 & 793,45 & \multirow[t]{3}{*}{ Digunakan } \\
\hline 2 & $Y=40,2669 \ln (X)-6,5634$ & 0,8726 & 68,844 & 53,999 & 4400,9 & \\
\hline 3 & $Y=18,2626(X)^{0,5153}$ & 0,9763 & 42,298 & 25,232 & 1661,3 & \\
\hline \multicolumn{7}{|c|}{ Titanium price index 9} \\
\hline 1 & $Y=4,8580(X)+23,9137$ & 0,9526 & 41,319 & $-36,005$ & 1585,3 & \multirow[b]{3}{*}{ Digunakan } \\
\hline 2 & $Y=45,2716 \ln (X)-14,4549$ & 0,8196 & 23,890 & 17,103 & 529,98 & \\
\hline 3 & $Y=15,1002(X)^{0,6997}$ & 0,9541 & 27,349 & $-21,663$ & 694,58 & \\
\hline \multicolumn{7}{|c|}{ Produksi konsentrat dunia ${ }^{[4]}$} \\
\hline 1 & $Y=19187,4982(X)-126098,102$ & 0,9383 & $1,46 \mathrm{E} 5$ & 6419,2 & $2,05 \mathrm{E} 10$ & \multirow[t]{3}{*}{ Digunakan } \\
\hline 2 & $Y=232710,63 \ln (X)-357167,17$ & 0,6482 & $4,15 \mathrm{E} 5$ & $3.69 \mathrm{~F} .5$ & $1,65 \mathrm{E} 11$ & \\
\hline 3 & $Y=991,3292(X)^{1,7753}$ & 0,9820 & $3,69 \mathrm{E} 5$ & $-3,0 \mathrm{~F}, 5$ & $1,29 \mathrm{E} 11$ & \\
\hline \multicolumn{7}{|c|}{ Konsumsi Zirkonium Indonesia ${ }^{[10]}$} \\
\hline 1 & $Y=1515,5498(X)+2792,3459$ & 0,9503 & 3894,7 & $-2663,9$ & $7,58 \mathrm{E} 6$ & \multirow{3}{*}{ Digunakan } \\
\hline 2 & $Y=3568,711 \ln (X)+3921,9594$ & 0,8512 & 917,39 & $-611,74$ & $4,21 \mathrm{E} 5$ & \\
\hline 3 & $Y=3979,7216(X)^{0,5830}$ & 0,9270 & 2719,7 & $-1864,1$ & $3,70 \mathrm{E} 6$ & \\
\hline \multicolumn{7}{|c|}{ Suku bunga bank ${ }^{[11]}$} \\
\hline 1 & $Y=-4,1947(X)+39,5453$ & 0,5447 & 19,632 & 16,576 & 289,07 & \multirow[b]{3}{*}{ Digunakan } \\
\hline 2 & $Y=-19,3408 \ln (X)+46,0830$ & 0,7988 & 10,406 & 8,9445 & 81,213 & \\
\hline 3 & $Y=55,8173(X)^{-0,9597}$ & 0,9576 & 2,9678 & 2.4789 & 6,6060 & \\
\hline \multicolumn{7}{|c|}{ Kurs rupiah/\$ ${ }^{[1]}$} \\
\hline & Rata-rata $=9.360,18$ & & 593,66 & & & Digunakan \\
\hline \multicolumn{7}{|c|}{ Inflasi $^{[11]}$} \\
\hline & Rata-rata $=7,70$ & & 2,93 & & & Digunakan \\
\hline
\end{tabular}

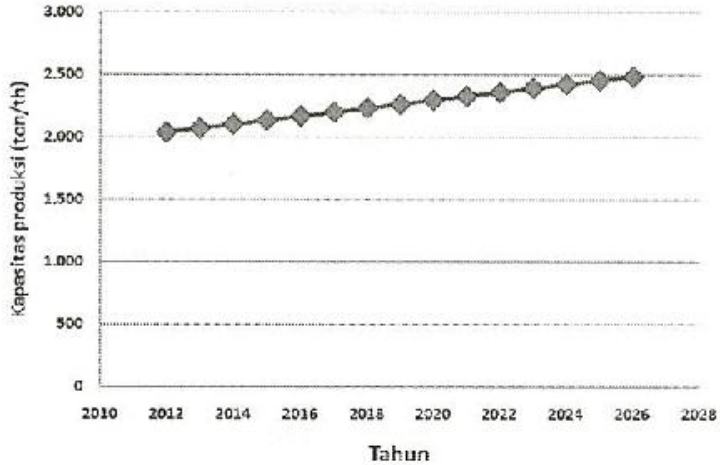

(a)

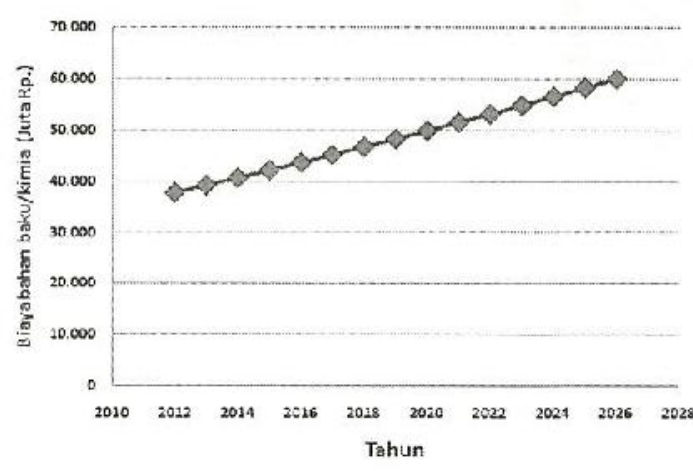

(b)

Gambar 4. Hasil Perhitungan: (a) Neraca Massa, dan (b) Biaya Bahan Baku/Kimia

\section{Biaya Peralatan}

Hasil peramalan dan perhitungan biaya peralatan untuk masing-masing grade dari tahun 2012 hingga tahun 2026 adalah seperti terlihat pada Gambar 5. Pada gambar tersebut terlihat bahwa biaya peralatan adalah scmakin meningkat dari tahun ke tahun. Hal ini disebabkan oleh, dalam peramalan peralatan adalah menggunakan kurva plant cost index (Tabel 2), yang kecenderungannya adalah selalu meningkat. 


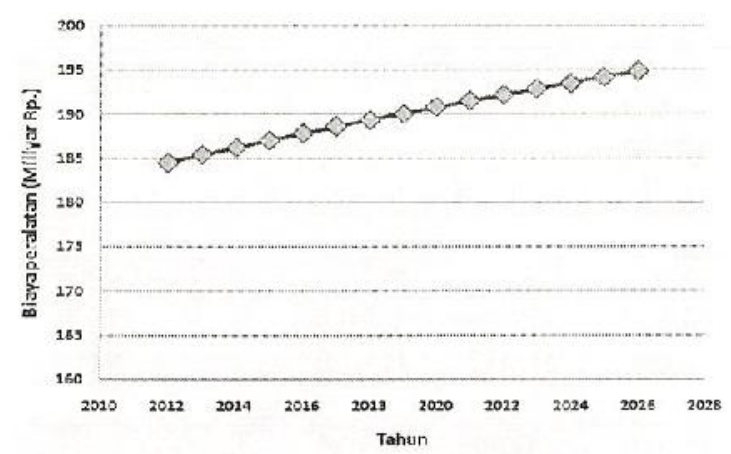

Gambar 5. Hasil Perhitungan Biaya Peralatan Pabrik Zirkonium grade $>\mathbf{9 0} \%$

\section{Biaya Karyawan}

Hasil peramalan dan perhitungan biaya karyawan untuk tiap-tiap grade pabrik Zirkonium dari tahun 2012 hingga tahun 2026 adalah seperti yang terlihat pada Gambar 6 . Berdasarkan gambar tersebut terlihat bahwa biaya kayawan adalah semakin meningkat dari tahun ke tahun. Hal ini disebabkan oleh adanya laju inflasi.

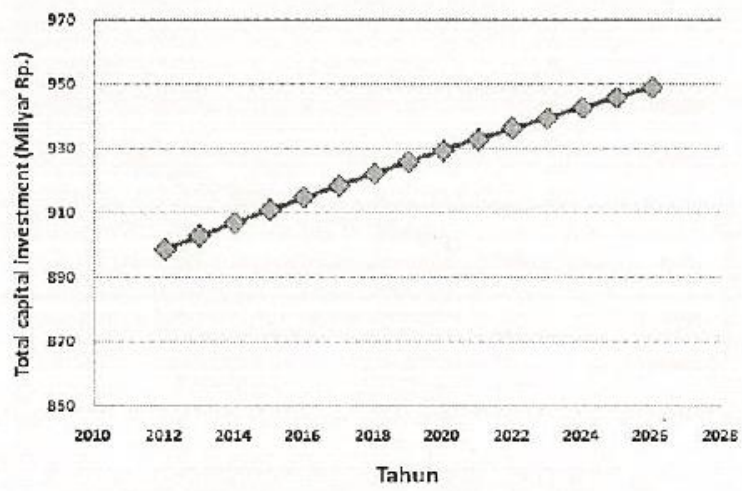

(a)

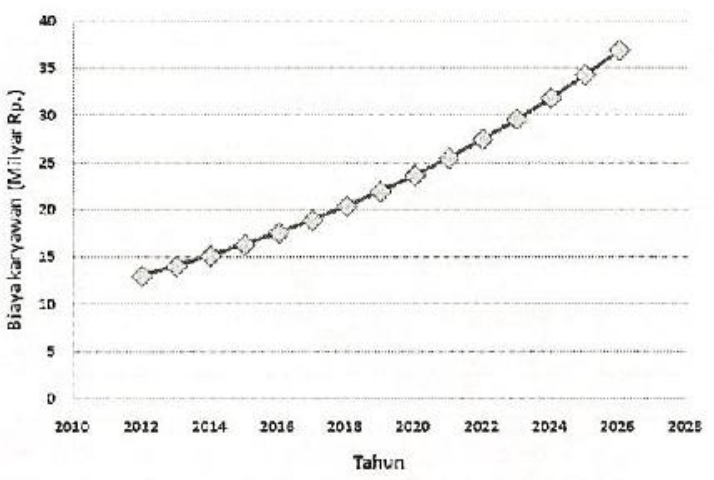

Gambar 6. Hasil Perhitungan Biaya Karyawan

\section{Biaya Investasi dan Production Cost}

Hasil perhitungan biaya investasi dan production cost dari tahun 2012 hingga tahun 2026 adalah seperti terlihat pada Gambar 7. Berdasarkan hasil perhitungan tampak bahwa untuk semua bentuk pembiayaan (capital investment dan total paroduction cost) akan mengalami kenaikkan seiring dengan berjalannya waktu. Hal ini dapat dipahami karena dari hasil peramalan menunjukkan bahwa seluruh komponen pembiayaan modal dan produksi adalah mengalami kenaikan seiring berjalannya waktu.

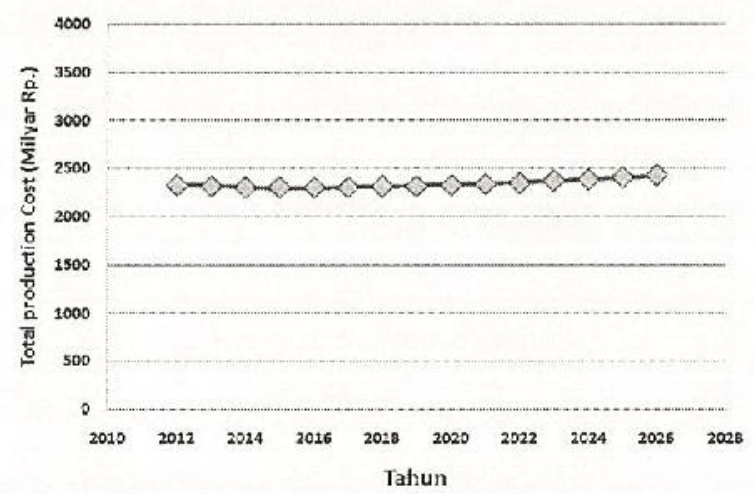

(b)

Gambar 7. Hasil Perhitungan: (a) Biaya Investasi dan (b) Biaya Produksi

\section{Penentuan Kapasitas Minimum Pabrik}

Hasil perhitungan masing-masing kelompok pembiayaan menunjukkan bahwa perkembangan biaya dari tahun ke tahun adalah selalu meningkat, sebab dari semua unsur perhitungan maka semakin lama waktu akan semakin naik harganya. Penentuan kapasitas minimum produksi dilakukan dengan Persamaan (10), yaitu dengan menentukan nilai
BEP-nya. Gambar hasil perhitungan dapat dilihat pada Gambar 8(a). Kapasitas minimum pabrik adalah titik potong antara garis Sa dengan garis Ra.

Perkembangan kapasitas minimum pabrik dari tahun ke tahun seperti terlihat pada Gambar 8(b). Berdasarkan gambar tersebut tampak bahwa kapasitas minimum pabrik semakin lama akan mengalami penurunan. Hal 
ini disebabkan oleh peningkatan harga jual produk yang tinggi dibandingkan dengan peningkatan pembiayaan lainnya. Dengan demikian semakin lama pabrik berproduksi

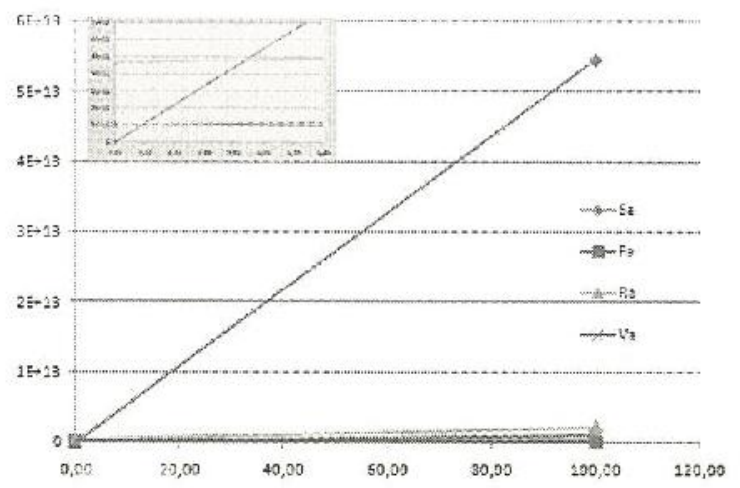

(a) Kapasitas minimum pabrik tahun 2012 maka pada kapasitas yang tetap akan didapatkan keuntungan yang semakin meningkat.

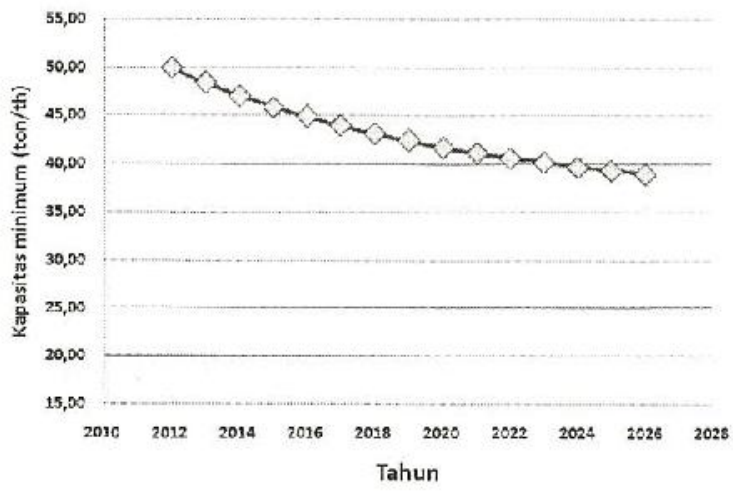

(b) Perkembangan kapasitas minimum pabrik

\section{Gambar 8. Kapasitas Minimum Pabrik dan Perkiraan Perkembangannya}

Hasil perhitungan menunjukkan bahwa pada tahun 2012, kapasitas minimum produksi pabrik adalah 49,55 ton/tahun. Sementara itu, kebutuhan produk Zirkonium pada tahun tersebut adalah 1095,40 ton/tahun. Berdasarkan hasil perhitungan di atas dapat disimpulkan bahwa pabrik dapat mencapai BEP pada tahun 2012. Untuk mengetahui perkembangan permintaan setiap tahunnya (2012 hingga 2026) dan perkembangan kapasitas minimum pabrik, maka disajikan pada Gambar 9.

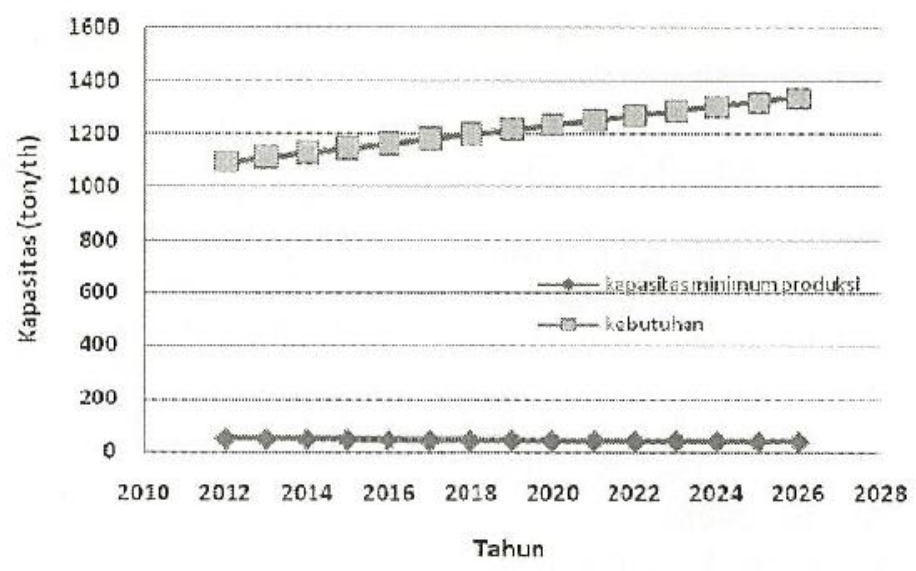

Gambar 9. Perkembangan Kapasitas Minimum dan Kebutuhan Zirkonium Grade $>\mathbf{9 0} \%$

\section{Penentuan Pay Back Periode (PBP)}

Berdasarkan hasil perhitungan sebagaimana tampak pada Gambar 10, PBP dapat tereapai pada bulan ke-55 atau pada bulan ke-8 tahun 2016, yaitu ditandai dengan besarnya keuntungan saat itu $(=\mathrm{Rp}$.
225.776.451.085,56) adalah lebih besar dari sisa pinjaman yang ada $(=\mathrm{Rp}$. 196.547.588.202,74). Dengan demikian seandainya seluruh keuntungan saat itu digunakan untuk membayar sisa pinjaman adalah telah mencukupi. 


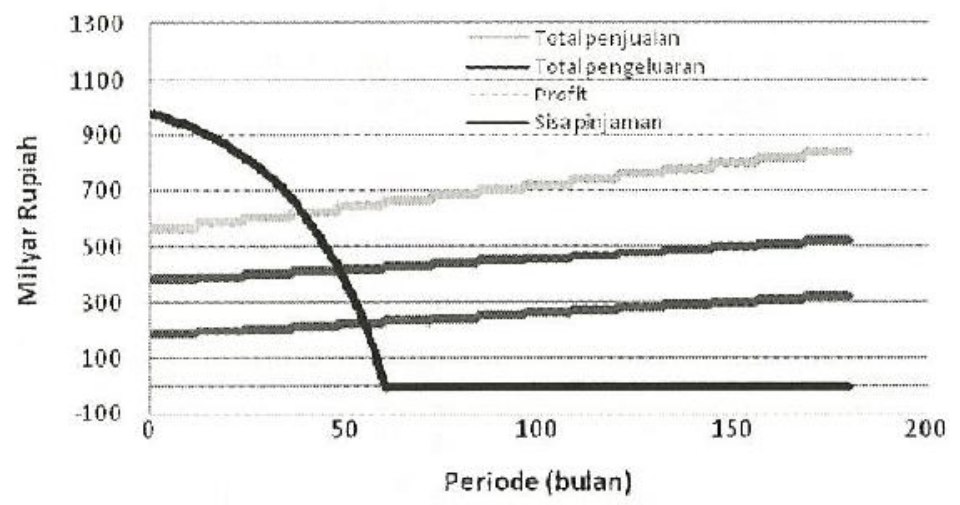

Gambar 10. Penentuan Waktu PBP Pabrik Zirkonium Grade $>90 \%$

\section{KESIMPULAN}

Berdasarkan penelitian yang telah dilakukan, pabrik ZOC dapat didirikan mulai tahun 2012 dengan kapasitas produksi $7 \mathrm{rOCl}_{2} .8 \mathrm{H}_{2} \mathrm{O}$ sebesar $2.040,2655$ ton/tahun, kapasitas terpasang $30.377,0358$ ton/tahun, dengan waktu yang dibutuhkan untuk pengembalian modal adalah 55 bulan operasi.

\section{DAFTAR PUSTAKA}

1. Henke, J.E. and Wichern, D.W., Business Forcasting, Eighth Edition, Pearson Prentice Hall, Pearson Education International, Upper Saddle River, New Jersey, USA, (2005).

2. Peters, M.S. and Timmerhaus K.D., Plant Design and Economics for Chemical Engineers, Fourth Edition, McGraw-Hill, Inc., Singapore, (1991).

3. Husnan, S. dan Muhammad, S., Studi Kelayakan Proyek, Unit Penerbit dan Percetakan, Yogyakarta, (2008).

4. USGS, Minerals Yearbooks Zirconium and Hafnium, US Department of the Interior, US Geological Survey, USA, (2010).

5. USGS, Minerals Yearbooks Zirconium and Hafnium, US Department of the Interior, US Geological Survey, USA, (1993-2009).

6. USGS, Minerals Yearbooks Zirconium and Hafnium, US Department of the Interior, US Geological Survey, USA, (2000).

7. James, R.C., Hertz, D.W., and Smith, F.L., Perry's Chemical Engineers' Hand Book, 8th Edition, McGraw-Hill companies, Inc., United States of America, (2008).

8. Sembodo, J., Prarancangan Pabrik Phenyl Ethyl Alcohol dari Benzene dan Ethylene Oxide Kapasitas 1000 ton/tahun, Tugas Akhir Jurusan Teknik Kimia, Fakultas Teknik, Universitas Muhammadiyah Surakarta, Surakarta, (2008).

9. ECONOMIC TIME SERIES PAGE, Series Title: PPI: Chemicals and Allied Products; NSA, diakses dari http://www.economagic. com/emcgi/data .exe/blswp/ WPU06, pada tanggal 24 Oktober 2011.

10. ESDM, Zirkon, Informasi Mineral dan Batubara, diakses dari http:i/www.tekmira.esdm.go.id pada tanggal 20 September 2011, (2011)

11. BANK INDONESIA, Suku Bunga Sertifikat Bank Indonesia, diakses dari http://www. bi.go.id/ web/id/Moneter/Operasi+ Moneter/' Suku+Bunga+SBL' pada tanggal 17 Juni 2011 , (2011). 